\title{
Effective Application of Communicative Approach in College English Teaching
}

\author{
Yanling Sun \\ School of Foreign Languages, Shangqiu Normal University, Shangqiu, Henan, 476000, China
}

Keywords: communicative approach, college English teaching, application; strategies.

\begin{abstract}
In the current employment environment, English is becoming more and more important, and good English ability is a basic condition for students' employment and development. Therefore, in the college English teaching practice, the English teaching shall be emphasized to improve students' comprehensive English quality. However, there are still some problems in the current college English teaching practice. The communicative approach is an effective English teaching method, which can effectively improve students' English application ability. The effective application countermeasure for the communicative approach in the college English teaching is expounded in this paper.
\end{abstract}

\section{Introduction}

English is a key discipline in the college education, and good English ability reflects the students' comprehensive quality directly. Influenced by the traditional teaching modes, there still are some problems in the current college English teaching, which also are the main obstacles to improving students' English ability. Therefore, how to solve these problems shall be considered by the college English teachers seriously. Communicative approach is a teaching method rising in the 1970s to train the learners' practical language communicative ability. As an innovative teaching mode, the effective application of communicative teaching in the teaching process has a very positive effect on stimulating students' interest in learning and promoting their English application ability. In this educational situation, it is of great practical significance to deeply analyze the application strategies of communicative approach in the college English teaching to improve the quality of college English teaching.

\section{Positive Significance of Application of Communicative Approach in College English Teaching}

\subsection{Giving full play to students' subjective initiative and improving the teaching quality}

In the classroom teaching process, teachers are only the guiders and participants in students' learning, and students are the main body of learning. In order to maximize the practical role of teaching and guide students to learn and explore the new knowledge initiatively, teachers shall actively guide students to fully play their dominant role. However, with the traditional teaching mode, teachers' explanation occupies most of the class time, so the students are generally lack of confidence, depend on teachers highly, and have no time to think independently in the learning process. In addition, they always are located in the passive position, and even if they have their own ideas, they dare not speak out directly. If things continue this way, the teaching efficiency will be affected seriously ${ }^{[1]}$. The application of communicative approach in the college English teaching can change this low-efficiency teaching mode, effectively excavate the students' own potential, stimulate the students' desire for exploring knowledge, make the students build up the good consciousness of subjectivity gradually, and respect students' personalized development in the learning process, so that they can fully play their subjective initiative, eliminate their fear of new knowledge in their learning process, establish the self-confidence, and improve their overall comprehensive constantly. 


\subsection{Stimulating students' interest in learning English}

It is discovered in the teaching practice that the interestingness of knowledge is in direct proportion to the students' acceptance level, that is, the more interesting the new knowledge points are, the higher the students' enthusiasm in learning will be, and the higher the students' acceptance and understanding level will be. However, under the negative influence of traditional teaching mode, the teachers' teaching methods are dull and monotonous, and the English knowledge is complicated to a certain extent, so students have difficulties in understanding and very easy to weary of learning, which are very bad for the effective development of the later teaching. The application of communicative approach in college English teaching can solve this problem effectively. By this method, teachers can stimulate students' interest in learning, allocate the teaching resources reasonably, enrich the classroom teaching content, overcome the defects and disadvantages of the traditional teaching mode, and help students eliminate the weariness of learning, so as to achieve the essential effect of college English teaching on the basis of full attention to the teaching interestingness in accordance with the students' learning characteristics and psychological development and the characteristics of English knowledge with teaching mode that is accepted by students most easily.

\section{The Basic Principles for the Application of Communicative Approach in College English Teaching}

\subsection{System principle}

In the teaching practice, knowledge is strongly systematic, so the system principle shall be followed in the learning process in order to avoid the separation of the integrity of knowledge that will cause disturbance of comprehension. Under the current background of network development, the fragmented information knowledge is full of the whole network. Influence by this, some teachers also carry out the fragmented teaching in the college English, and do not pay attention to the continuity of knowledge, so that students are also learn one-sided knowledge without systematic understanding and cannot associate the relevant knowledge timely in the practical application, which has a greater negative impact on the learning effect ${ }^{[2]}$. Therefore, in order to effectively improve the overall quality of college English teaching and play the practical role of communicative approach, we shall pay attention to the systematicness of knowledge, and make rational planning in the application process of the communicative approach, help the students establish a complete knowledge system, straighten up the context of knowledge, find the key connection points with the course education objectives as the principal line, penetrate the communicative approach into all links of teaching, and grasp the systematicness and integrality of knowledge.

\subsection{Subjectivity principle}

In the learning process, students are not the passive receivers of knowledge, but shall initiatively and constantly enrich and improve the new knowledge and build a knowledge framework in order to improve the comprehensive quality in accordance with their existing knowledge system. However, under the traditional educational concept, the students' initiative has not been played maximally, their dominant role in the classroom has been completely replaced by teachers' explanation, and they learn completely according to teachers' thinking without the initiative thinking process. Meanwhile, various rules and regulations also limit the students in the existing space, so that their creativity and learning thought can not be effectively played and the overall teaching quality is affected. Therefore, while using the communicative approach in the college English teaching, teachers shall pay full attention to the students' dominant position, actively create new teaching mode, play their guiding role, improve students' subjective initiative, guide the students to think actively and initiatively, and change the teaching disadvantages of accepting the knowledge passively in the past, in order to make students gradually develop an independent learning habit, enhance the confidence in learning, and lay 
a solid foundation for the deep study in the future.

\section{Main Problems in the Application of Communicative Approach in College English Teaching}

\subsection{The teaching content is not planned and arranged scientifically and reasonably}

For students, whether the teachers' teaching contents are scientific and reasonable is very critical in the learning process, which is directly related to the students' acceptance and understanding levels. For the same knowledge content, if the teacher has planed it scientifically and reasonably before class and carries out the teaching activity strictly in accordance with the established plan during the teaching process, students will accept and understand the knowledge fast, but on the contrary, their learning will be affected. In the current teaching practice of college English, the application of communicative approach is not very scientific. In order to get the overall quality and teaching effect, some teachers only indoctrinate students with the theoretical knowledge and make the teaching plans according to their own wills, who simply think that students' comprehensive quality will be improved as long as the teaching standard is improved. Therefore, they ignore the characteristics of students' learning and growth in the teaching practice, which leads to the unconformity of students' learning with their actual intelligence development, so that the expected role of the teaching quality is not played, and students' future learning may be affected greatly.

\subsection{The application of communicative approach is too formalized without substantive significance}

The new course reform has been conducted for a period of time and has achieved some preliminary results. With the course reform, some new teaching methods have emerged gradually, among which some are very effective to change the traditional teaching forms and the teaching concept in the teaching process and improve the overall quality of teaching greatly. However, there are still some problems in this process, and the communicative approach is a representative among them ${ }^{[3]}$. Due to the influence of inherent teaching concept, some teachers have low acceptance of communicative approach and some deviations from the understanding. Moreover, in the practical application process, these teachers are influenced by the trend of course reform and the innovation of teaching mode. As a result, this approach is only applied in form, and some teachers ignore the original teaching objective due to the excessive attention to the teaching form. Superficially, these teachers apply the communicative approach well, but in fact, they do not play the expected role of this approach, and sometimes even spend a lot of time on the teaching form, which affects the overall quality of teaching, which is not worth the candle.

\subsection{Lack of effective communication with students in the teaching process}

The classroom teaching process is also a communication process between students and teachers. Through the effective communication, the teachers can know and master the students' learning states, simply explain the knowledge points that all the students have understood, and explain the problems that most students have pertinently. In this way, not only a lot of valuable classroom time can be saved, but also the overall efficiency of classroom teaching can be improved. However, all above are based on effective communication between teachers and students. If there is a lack of communication between teachers and students or the communication is poor, the students' actual learning situation will not be mastered by teachers in time, there is no pertinence in the teaching process, and the students will follow the teachers' ideas completely without independent thinking process, which are the ubiquitous problems in the current college English teaching by the communicative approach. These are the common problems in the application of communicative approach. Under such circumstances, the adoption of any teaching measure is blind and is lack of pertinence. 


\section{Countermeasure for Effective Application of Communicative Approach in College English Teaching}

\subsection{Deepen teachers' understanding of communicative approach and effectively improve the English teaching quality}

In the students' learning process, teachers are critical. In a manner of speaking, teachers' comprehensive quality has an important influence on the students' learning, which is directly related to the students' mastery and understanding of knowledge. Therefore, in the college English teaching practice, in order to improve the teaching quality and promote the better application of communicative approach, we shall make more efforts to improve teachers' teaching quality. Especially in the background of the deep implementation of teaching reform, the new teaching methods are constantly emerging. Only teachers have high professional quality and profoundly understand the substantive requirements of communicative approach, they can make appropriate choices in the teaching process and maximize the practical role of communicative approach, to improve the actual effect of college English teaching ${ }^{[4]}$. In this process, the colleges can actively organize teachers to carry out the teaching exchanges, learn from each other on the problems and experiences in the teaching process, so as to deepen the teachers' understanding of the classroom teaching and make them continue learning the excellent teaching methods, thus laying a foundation for the better application of communicative approach.

\subsection{Set clear teaching objectives and improve the pertinence of communicative approach}

In the current college English teaching process, the unclear teaching objective is one of the main problems that affect the improvement of teaching quality and the application of communicative approach. In order to solve this problem fundamentally, the teachers shall set up clear teaching objectives before teaching. To be specific, teachers shall follow the syllabus, deeply understand the students' English learning situation and their mastery degree of knowledge on the premise of accordance with the standard of college English teaching, and then make scientific and reasonable teaching objectives combined the course standards. Besides, they shall abandon the past wrong teaching method of random teaching-hours arrangement according to their own wills, help students establish a complete mathematical knowledge system through scientific teaching design, give consideration to the review of the knowledge learned while explaining the new knowledge, and promote the better application of the communicative approach, so that students can not only review the knowledge learned in the classroom teaching process, but also learn the new knowledge to form a benign teaching cycle and gradually improve students' comprehensive quality.

\subsection{Strengthen the communication between teachers and students, and solve the problems in the teaching process in time}

Communication is a main way to understand students, and it is also a basic condition for teachers to perfect the teaching mode and improve the teaching quality. Therefore, in order to promote the better application of communicative approach in the college English teaching process, teachers shall actively communicate with students to know their learning situation and the existing problems in time, and then adjust the application form of the communicative approach ${ }^{[5]}$. When students encounter some problems in the learning process, teachers can't blame the students blindly, and shall treat them differently according to the specific conditions, explain the individual problems to the individual students, and strengthen the common problems with pertinence, which can help students clear the obstacles in the learning process and improve their comprehensive quality. When students encounter some problems that are difficult to be solved, teachers shall carry out the appropriate psychological guidance to help students build the confidence in learning, eliminate their fear of new knowledge, and make them face their own problems to avoid the impact of fear of difficulty, and then adjust the teaching program in time according to the students' actual learning situation to improve the 
pertinence and effectiveness of college English teaching.

\section{Conclusion}

To sum up, the communicative approach is an effective teaching mode, and its application in the college English teaching has a very positive effect on improving the teaching quality. Therefore, teachers shall pay more attention to the communicative approach, and constantly innovate and improve the application strategy of communicative approach in the teaching practice, deepen the understanding of this approach, make scientific and rational teaching objectives, maximize the practical role of communicative approach, and solve the problems in the application process in time, to improve the quality of college English teaching.

\section{References}

[1] Li Xiaoyan, Enlightenment of Communicative Approach to Employment-oriented College English Teaching, Modern Vocational Education 2017(22): 31.

[2] Chen Lijun, Application Exploration of Communicative Approach in College English Teaching, Campus English (published the last ten-day period of each month) 2017(10): 17-18.

[3] Li Xiaoqin, Application of Communicative Approach in College English Teaching, Journal of Chifeng University (natural science version), 2014(18): 221-222.

[4] Ma Lin, Teaching of Reading and Writing of College English from Perspective of Communicative Approach , New Campus (published in the first ten-day period of each month), 2017(3): 21 .

[5] Pang Jin, Liang Xiufang, Application of Communicative Approach in College English Teaching, Journal of Hebei Engineering and Technology College, 2016(4): 66-67. 